УДК 7.03: 739.2(477.4)«10-12»

DOI https://doi.org/10.24919/2308-4863.5/28.208927

Ольга ШКОЛЬНА,

orcid.org/0000-0002-7245-6010

доктор мистецтвознавства,

професор кафедри образотворчого мистецтвв Киїського університету імені Бориса Грінченка

(Київ, Україна)

Олександра БАРБАЛАТ, orcid.org/0000-0001-8682-9247 викладач ювелірного мистецтва, аспірантка кафедри образотворчого мистечтва Київського університету імені Бориса Грінченка

(Київ, Україна) alexandrabarbalats@gmail.com

\title{
КИЄВОРУСЬКІ ЗІРЧАСТІ ТА ДИСКОПОДІБНІ КОЛТИ З ЧОРНІННЯМ В УКРАЇНСЬКИХ І ЗАКОРДОННИХ КОЛЕКЦІЯХ: ДЖЕРЕЛА ІНСПІРАЦІЙ
}

Дослідження присвячено мистецтвознавчому осмисленню києворуських зірчастих $i$ дископодібних золотих $i$ срібних колтів з чорнінням. Окреслено інформацію про історичні передумови виникнення чільцеподібних прикрас на теренах Київської Русі. Висвітлено культуротворчі взаємини між східними народами, починаючи від кіммерійців і скіфів, котрі мали іранське коріння та були близькими в окремих напрямах творчості ассирійиям, з русичами, які також були носіями традичій прикрамання головних уборів з бічними підвісками з обважнювачами. Так звані колти - скроневі підвіски - були модними жіночими церемоніальними прикрасами головного убору Київської Русі в середині XI - на початку ХІІ століть. Дані ювелірні вироби містили невеликі шматочки тканини, наповнені ароматичними оліями або травами. Понад 20 пар ичих елегантних і розкішних прикрас збереглися до наших днів. Кожна пара унікальна за свойм дизайном та мотивами, що дозволяє припустити, що всі вони були виконані під замовлення.

За останні 200 років у центральній, аристократичній та укріпленій частині середньовічного Києва було знайдено значну кількість малих і великих скарбів. Більшість із них було виявлено випадково (під час прокладки водопроводів чи водостоків, копання фундаментів, створення доріг тощо), недалеко від старих монастирів та иерков, де під час бурхливих часів їх закопували в землю для їх захисту. Ці обереги, до яких входили вироби з князівського одягу та релігійні предмети, складалися, головним чином, з ювелірних виробів високої художньої майстерності. Окрім інших дорогочінних предметів, серед них були і скроневі підвіски, відомі як колти. Відкриття иієі великої кількості ювелірних прикрас, котрі за своїми художньо-стилістичними особливостями вказують на те, щчо Київ розвивав власні золоті майстерні та традичї, має велике значення для осягнення зв 'язків Києворуської держави з європейськими, азійськими й африканськими країнами.

Здійснено спробу охарактеризувати ичентри Києворуської держсви, де виготовляли означені вироби та носили. Розглянуто час побутування виробів, а також художні особливості прикрас, способи їх носіння. Окреслено основні різновиди експонатів, відомих за українськими колекціями, а також за реконструкціями. Уточнено технічні особливості виконання творів, специфічні ознаки оригінальних колтів.

Ключові слова: колти зірчасті, колти дископодібні, колти з чорнінням, зернь, Київська Русь, ХI - перша половина ХІІІ століть.

Olga SCKOLNA, orcid.org/0000-0002-7245-6010 Doctor of Arts, Professor of Fine Arts Borys Grinchenko Kyiv University (Kyiv, Ukraine)

Oleksandra BARBALAT, orcid.org/0000-0001-8682-9247 Teacher of Modern Jewelry Art, Graduate Student of the Department of Fine Arts Borys Grinchenko Kyiv University (Kyiv,Ukraine) alexandrabarbalats@gmail.com 


\section{STAR-SHAPED AND DISC-SHAPED SILVER KOLTS WITH NIGELLUS FROM KIEVAN RUS IN UKRAINIAN AND FOREIGN COLLECTIONS: INSPIRATION SOURCES}

This research is devoted to the understanding of the star-shaped and disc-shaped gold and silver kolts with nigellus. It outlines the information on historical preconditions for the apperance of ring-shaped ornaments on Kyivan Rus territory. The research highlights the cultural and creative relations between the Eastern peoples, starting with the Cimmerians and Scythians, who had Iranian roots and were close in some areas of creativity to the Assyrians, with Russians who were also bearers of the tradition of decorating headgear with side hangers. So called kolts were fashionable women's ceremonial headdress ornaments of Kyivan Rus in the middle of the XI-beginning of the XII centuries. These jewelry pieces contained small bits of fabric filled with aromatic oils or herbs. More than 20 pairs of these elegant and luxurious jewelry have survived to this day. Each pair has unique design and motives, suggesting that they were all custom made.

Over the last 200 years, a large number of small and large treasures have been found in central, aristocratic and fortified parts of medieval Kyiv. Most of them were discovered by accident (when laying water or gutters, digging foundations, building roads, etc.), not far from the old monasteries and churches where they were buried in the earth during turbulent times to protect them. These amulets, which included princely articles and religious items, consisted mainly of high-quality jewelry. In addition to other precious items, there were decorative headgear with side pendants known as kolts. The discovery of this large amount of jewelry, the artistic and stylistic features of which indicates that Kyiv developed its own gold workshops and traditions, is of great importance for understanding the connection of the Kyivan Rus relations to European, Asian and African countries.

An attempt has been made to characterize the centers of the Kyivan Rus state where these items were made and worn. The time of life of products, as well as artistic features of jewelry, ways of wearing them are considered. The main varieties of exhibits found in Ukrainian collections as well as item's reconstructions are outlined. Specified technical features of the works, specific features of the original kolts.

Key words: star-shaped kolts, disc-shaped kolts, silver nigellus kolts, silver granulated technique, Kyivan Rus, XI - first half of XIII centuries.

Постановка проблеми. Останнім часом переглядаються хронологічні межі існування певних пластів художньої культури на вітчизняній території, уточнюється зміст окремих понять і дефініцій. У зв’язку з цим переосмислюються й надбання певних періодів у галузі мистецтва. Адже вимоги до історіографії доби XX століття за штучної асиміляції деяких процесів під призмою загальнорадянської історії дещо неоднозначно пропонували тлумачити деякі здобутки певних територій, виводячи їх у контекст давньоруської культури.

Нині науковий дискурс в означеній царині дозволяє розглядати власне києворуську спадщину країни з центром у Києві як самодостатню і викінчену в межах тогочасного існуючого адміністративно-територіального устрою. У цьому зв’язку мистецькі артефакти дозволяють краще зрозуміти точки перетинів художньої культури окремих осередків, їхні спільні чи різні творчі прерогативи та факти певного єднання за тогочасною модою.

Аналіз досліджень. 3 огляду на вищевикладене особливий інтерес у контексті розглядуваної теми становлять києворуські колти, знайдені в Києві та Чернігові, а також на землях етнічної Росії у Пскові, Новгороді, Рязані, Калузі та Підмосков $\dddot{\text {. }}$

Походження колтів низка вчених, починаючи 3 доктора мистецтвознавства, професора-візантолога Н. Кондакова (Кондаков, 1896: 96-97), доктора історичних наук, археолога Т. Макарової (Макарова, 1975: 15-21), доктора історичних наук, професора С. Рябцевої (Рябцева, 2017: 499-510), (Рябцева, 2005: 169-199), вважала пов'язаним із візантійськими прикрасами. Перший з означених науковців правильно визначив, що загальний прототип місячних (серповидних) прикрас був сприйнятий з теренів Сирії і поширювався як у Візантії, так і на Русі й у народів Причорномор'я. Причому у двох останніх ареалах культур автономно розвивався свій, не тотожний візантійському тип місячних колтів, що наближався до більш «варварських» об'ємних прикрас-ароматниць (Ароматические колты, 2018).

Так, у візантійській провінції Кримській Готії побутували як пласкі, так і об'ємні різновиди, що кріпилися до головних уборів на ціпках. Деякі 3 них, виконані із золота, на думку візантологамедієвіста, доктора мистецтвознавства, професора Н. Кондакова, призначалися для поховального обряду (Кондаков, 1896: 96-97). 3 погляду доктора історичних наук, археолога О. Айбабіна їхня ґенеза напряму пов'язана 3 культурою хазар кінця VII - першої половини VIII століть. Адже цю тезу підтверджують підвіски з жіночого поховання в Новопокровці (Східний Крим), прикрашені різнобарвними скляними вставками (Айбабин, 2013: 277-315).

Деякі різновиди колтів, наприклад, зірчасті, i ïx східна генеза були, досліджені доктором 
історичних наук, археологом Н. Жиліною, котра намагалася дати визначення не лише типології форм цих виробів, а й тлумаченню семантики окремих мотивів (Жилина, 1997: 140-150). Остання згадана авторка також вважала, що кулясто-лунничні різновиди прикрас у Київській Русі розвивалися паралельно з візантійськими, маючи власну лінію формотворення, не перехрещену з Другим Римом (Жилина, 2018: 269-275).

Києворуським колтам і їхній варіативності форм та декору присвячені окремі публікації доктора історичних наук, професора, академіка $\mathrm{AH}$ СРСР Б. Рибакова. Так, означений вчений упродовж кінця 1950-х - 2000-х рр. розглядав мотив іранського собако-птаха Семаргла (Сенмурва) в язичницькому пантеоні Київської Русі (Рыбаков, 1971), (Рыбаков, 1967: 91-116). Також колтам та їхнім художнім особливостям, замішаним на перському складнику, були присвячені окремі сторінки статті по іконографії Семаргла та монографії доктора історичних наук М. Васильєва 1999 р. «Язичництво східних слов'ян напередодні хрещення Руси» і «Релігійно-міфологічна взаємодія з іранським світом» (Васильев, 2017: 187-206), (Васильев, 1999: 206-300).

Мета статті - висвітлити художні й технологічні особливості києворуських зірчастих, дископодібних золотих і срібних з чорнінням колтів 3 вітчизняних і закордонних музейних колекцій.

Виклад основного матеріалу. Загалом, слід зазначити, що чільцеподібні прикраси прийшли до теренів Київської Русі через традиції східних народів. Так, починаючи від кіммерійців і скіфів, котрі мали іранське коріння та були близькими в окремих напрямах творчості ассирійцям, з якими русичі мали певні культуротворчі взаємини, існувала традиція носіння головних уборів з прикрасами, що завершувалися бічними підвісками 3 обважнювачами. Ця конструктивна деталь одягу прижилася в багатьох східних народів, оскільки знімним обручем або пов'язкою-стрічкою на повітрі притримували плат на голові, котрий прикривав голову й обличчя від сонця.

Така прикраса спочатку мала чисто утилітарну функцію - захистити свого власника від теплового або сонячного удару і шкіру обличчя від згорання. А власне обважнювачі не давали плату чи убрусу під час поривів вітру зірватися 3 голови, аби не залишитися незахищеними просто неба. Так, досі в арабських та інших спекотливих країнах, зокрема в Ірані, Сгипті, Сирії тощо, притримують головний убір.

3 часом підвіси на головному уборі номадівкочовиків стали урізноманітнюватись, набували мистецьких ознак і їхні обважнювачі, які інколи трансформувалися в окремі скроневі чи завушні «колтки» (елементи, що розхитувалися, колтихалися на вітру та під час ходіння) або й сережки. Зокрема, це чітко прослідковується за трансформацією налобних, скроневих і вушних прикрас зі скіфських курганів (Історія українського мистецтва, 2008: 211-227).

Так, кандидат історичних наук, археолог О. Фіалко в першому томі «Історії образотворчого мистецтва України» зазначає, що «y V столітті до н.е. скіф'янки виявили цікавість до човникоподібної (або місяцеподібної) моделі сережок» (Історія українського мистецтва, 2008: 211-227). Подібні твори, на думку вказаної авторки, походять від образу місяця-човника 3 образотворчого мистецтва Середземномор'я II тисячоліття до н. е. Часто їх форма в ювелірному мистецтві доповнювалася зображенням голови водоплавної качки, що була символом трьох стихій i, відповідно, родючості. Такі прикраси, інколи з чорнінням, із шумелінням-підвісами знизу швидше за все несли ознаки обрядових (шлюбних) предметів (Історія українського мистецтва, 2008: 211-227).

Надалі давньогрецькі скроневі підвіски у вигляді рондального диску і лунниці із шумелінням-підвісками 3 амфорисками на кінцях, всередині кола якої була зображена голова богині Афіни, носили в Криму. Подібні предмети, декоровані всередині рондо і частково в деяких 3 деталей емалями, відомі від V-IV ст. із розкопів Куль-Обинського кургану в Криму (Історія українського мистецтва, 2008: 227-507).

Вважається, що в таких виробах (як скроневих підвісах, так і сережках) прослідковується поєднання двох найдавніших типів кольчиків - дископодібних і човникоподібних (серповидних). Деякі з них, як свідчить кандидат мистецтвознавства доцент М. Русяєва, в означений час доповнювалися зерню (Історія українського мистецтва, 2008: 508-509).

Поєднання двох вищеозначених типів традицій - іранської і давньогрецької поступово призвели до утворення на територіях Криму так званого «стилю елліно-скіфського мистецтва». У його симбіозі знайшли віддзеркалення високі грецькі естетичні канони нанесення філігранних зображень (пост-Фідієвського часу) і високоякісні технічні властивості скіфо-сарматських (де-факто іранських) традицій торевтики, похідних від срібла Ахеменідського Ірану 3 чорнінням, інколи в поєднанні з амальгамною позолотою й, подеколи, гарячими емалями та 
інкрустацією кольоровим склом (Хайрединова, 2017: 86-99).

Пізніше хвилі номадів, обмін данню та перетрактації всередині іраномовних племен призвели до появи рефлексій золотарства Сасанідів, що відоме на весь світ своїми техніками срібних ювелірних виробів. Власне, і непересічна скіфська золота пектораль із Товстої Могили (сучасна Дніпропетровська обл.) IV ст. до н. е. демонструє уподобання цього населення щодо серповидних форм ювелірних виробів. Надалі інші тюркські племена, споріднені зі скіфами, зокрема алани та половці, кочуючи великими територіями від українських земель до Кавказу, впливали на моду щодо головних уборів на просторах від Візантії до Київської Русі.

Принагідно варто зазначити, що у скіфів під впливом високого грецького мистецтва поступово зооморфні образи були витіснені антропоморфними. Ці трансформації з часом знайшли відображення й у мініатюрах києворуських колтів. Адже від другої половини II-III століть нашої ери підковоподібні підвіски-лунниці (Лунничные серьги и колты) з виїмчастими емалями увійшли внаслідок технологічних досягнень римського часу у виробництві скла в побут представників так званої київської культури (Історія українського мистецтва, 2008: 600-623).

За скарбом люду 3 останньої, датованого III-м ст. н.е., з Межигір'я під Києвом, за реконструкцією кандидата історичних наук, археолога Є. Гороховського й історика-археолога, етнокультуролога П. Корнієнка, відомо, що комплект тогочасних прикрас складався 3 чільця-діадеми та круглих блях на ціпкових звисаючих ряснахпідвісах (Історія українського мистецтва, 2008: 623-624).

Надалі, $з$ удосконаленням техніки, від межі X-XI століть на вітчизняних територіях, куди інколи потрапляли візантійські монети-соліди із зображенням царгородських імператорів 3 підвісками до них, так званими «препендаріями», закріпилася мода на подібні вироби в колах істеблішменту із виїмчасто-перегородчастими емалями та рельєфними візерунками 3 черню. Власне, з цих само монет були запозичені взірці візантійських корон, поширені в окремих провінціях імперії кшталту Грузії, а-ля ірансько-тюркські, що нагадували половецько-аланські шапкитюбетейки 3 хутряним відворотом 3 опушкою. Про це свідчать дослідження кандидата історичних наук, доцента О. Брайчевської (Брайчевська, 1993: 112-117). Враховуючи, що більшість києворуських князів виховувалися в половецьких ста- нах у своїх матерів, такі уподобання видаються цілком зрозумілими. Подібні головні убори мали східні першовзірці, насамперед ірано-кавказькохазарської генези, які набули поширення в колах грузинської знаті (характерний приклад - зображення царя Давида, який мешкав наприкінці XI - на початку XII ст.).

Ще один фактором підтвердження зв'язків вітчизняних колтів 3 перським сріблом є факт поширення в них техніки чорніння (Макарова, 1986: 15-16). Причому останні розповсюдилися в слов'янському соціумі саме наприкінці XI - на поч. XII століть і по своїй зооморфній орієнтації малюнків рельєфів на торевтику в окремих сегментах наближалися до прототипів 3 емалями. Однак колти з черню, що виготовлялися в києворуських центрах золотарства, найчастіше містили зображення Семаргла, не характерне для емалевого ансамблю прикрас головного убору 3 убрусом.

Відомо, що іранські першовзірці з чорнінням часто доповнювалися золоченням. Саме такі вироби здебільшого виконувалися на замовлення істеблішменту, і їх виробництво локалізувалося саме в осередках міської культури. Джерелом інспірацій на наших територіях, крім сиро-персько-візантійських (Даркевич, 1975: 287-350) векторів, для майстрів давніх Києва та Чернігова були також ординські вироби, що осідали на наших землях після вторгнень. Здебільшого вони прикрашалися вишуканими техніками зерні та скані. Тому естетика творів східного походження часто була цим творам близькою.

Оскільки відомі колти (ковтки) (Словник української мови, 1996) кулястої та зірчастої форм, можна зазначити, що обидві з них були представлені на Русі в сріблі. Натомість золоті такі вироби в основному мали серповидну форму й оздоблювалися виїмчасто-перегородчастими емалями 3 мотивами сиринів та алконостів, птахів, зображень святих, Ісуса та Богоматері. При цьому зірчасті колти з білого та жовтого металів одночасно прикрашалися зерню та сканню. Для срібла тоді використовували техніку діфування (діфовки) - ручної виколотки візерунку, котрий відтінювався черню та позолотою. А зірчасті вироби в означену добу додатково часто оздоблювали крихітними кільцями, на які напаювали мікроскопічні зернятка срібла (Макарова, 1986: 7-15).

Мистецтво черні могло прийти до києворуських ювелірів двома шляхами. По-перше, з візантійських провінцій, близьких до Ірану, а саме 3 Кавказу. Адже відомо, що означена техніка була 
відома у Грузії від Х століття (приклад - ікона Спаса 3 Целенджі та виносний Ішхадський хрест (Макарова, 1986: 26-28), і за посередництва тюркських народів або ж власне греківвізантійців, яких у великій кількості запрошували на Русь, у тому числі через Крим, могла відбутися передача секретів виробництва. Інше джерело - це ірансько-сирійські вектори взаємодії, зокрема через майстрів-мініатюристів рукописів.

Натомість появу зерні на теренах Київської Русі, за Т. Макаровою, варто пов'язувати 3 технологіями, поширеними перед тим від Х століття на землях Чехії та Польщі. У Києві та Чернігові означені дві техніки прижилися в другій половині XI століття, одночасно з опануванням від грецьких майстрів золотарства мистецтва перетинчастої емалі (Макарова, 1986: 26-28).

Останнє застосовували найчастіше під час виконання частин так званих ансамблів налобної прикраси чільця-діадеми зі скроневими підвісами-усєрязями з підважувачами-бляхами, що, модифікуючись упродовж XI століття, отримали вигляд порожнистих усередині колтів, які ароматизувались пахучими тканинами або запашними травами (Брайчевська, 1993: 112-117). Однак свого високого розвитку перші дві названі техніки в Київській Русі набули вже в другій половині XII - на початку XIII століть.

Принагідно варто зазначити, що на колти й інші прикраси весільного костюму насамперед наносилася поганська символіка, орієнтована підсилювати родючість. Передусім зображувалися парні Семаргли-Переплути (Рыбаков, 1967: 91-116) 3 їхнім невід'ємним атрибутом - плетінкою або ж грифоноподібні чи голубоподібні птахи 3 деревом життя та криновидними (штибу лілей-пік) елементами (Рис. 1). Означені композиції були покликані втілювати ідею розвитку життя, запліднення. Часто архітектоніка вказаних мотивів наближається до візерунків різьбярів по каменю, що споріднює мистецтво названих галузей означеного часу. Цебто свідчить про джерела інспірацій окремих малюнків і долучає ïx до кола образів і сюжетів, пов'язаних з естетичними уподобаннями замовників-містобудівничих.

Так, Н. Жиліна унаочнює образну єдність зірчастих колтів із зерню з бб'ємно-геометричним стилем розвитку києворуського мистецтва і датує такі вироби першою половиною - серединою XII століття. Однак поширення таких різновидів виробів окреслює, окрім Києва й Чернігова, і центрами в етнічній Росії, зокрема Старої Рязані та
Терехово сучасної Орловської області (Жилина, 2018: 269-275). Причому в поданих нею зразках довкола чорнених опуків фасадної частини виробів по колу розташовувалися крупні краплі зерні або й намистини з перлів (так звані обнизі). У такому вигляді подібні вироби з типово місячних набували ознак сонячно-солярних, що віддзеркалює трансформації свідомості.

В останньому вказаному населеному пункті авторка наводить і локалізацію знахідок кулястих колтів із зображенням парних Семарглів тієї ж доби (перша половина - середина XII ст.). Натомість колти 3 перегородчастими емалями (Макарова, 1975: 127-128) вона датує кінцем XII - першою третиною XIII ст. і визначає їх як вироби власне київських майстрів (Жилина, 2018: 99-101). Відомо, що такі виключно князівські твори перед самою монголо-татарською навалою на початку XIII ст. стали виготовляти в більш дешевих варіаціях - відливали з бронзи та свинцю й здійснювали продаж речей на ринках. Після нашестя їх виготовлення вже не відновилося (Коруны, усерязи, колты).

Срібні колти XI - початку XIII ст. стали відомі за розкопками В. Хвойка початку XX ст. на Черкащині. Зокрема, в цій місцевості побутували в означений час шестипроменеві срібні, а також колти із зображеннями грифонів й золоті 3 мотивами птахів. Надалі подібні прикраси знаходили у Володимирі й інших києворуських містах (Жилина, 1997: 98-115). Частково такі колти княжо-боярської світської верхівки у композиційному плані наслідували прикраси у вигляді золотих підвісів, що звисали 3 головного убору візантійських імператорів, під назвою препендулії. При цьому колти з черневим візерунком вказаного періоду з одинарним або парним мотивом Семаргла могли робитися в княжих майстернях Чернігова разом з емалевими (Макарова, 1986: 51-156).

3 часом обнизі довкола колтів із чорнінням 3 образами парних Песо-птахів трансформувалась з відлитих елементів у тиснені половинки зерняток, надалі спаяних в єдину кульку (Макарова, 1986: 51-52). Згодом їх знаходили в Рязані й інших населених пунктах етнічної Росії, де означені твори могли й виготовлятися. Пізні різновиди таких виробів з черню характеризувалися переходом від зооморфних мотивів до орнітоморфних, а довкола диска колту опоряджувалися променеподібні перетинки.

Спочатку на їхніх кінцях трималися зернини (імітація перлової обнизі), як у кримських виробах візантійського часу XI століття з Лучистого, 
Новопокровки, Верхріччя, Херсонесу із зображенням різноманітних птахів (павичів тощо) та благовоннями всередині корпусу (Жилина, 2018: 275-279). Надалі ці променці були обпаяні між собою довколишньою каймою, що у сукупності утворювала рондальне зовнішне коло. Означені вироби локалізувалися в Києві, Переяславлі, Новгороді, Ізяславлі. При цьому інколи чернь на них замінювалася чорною емаллю (Макарова, 1986: 60-63).

Натомість зірчасті києворуські колти із зерню $\epsilon$ типовим відлунням візантійської ювелірної моди IX-XII ст., що фіксується за творами з іноземних колекцій - Британського художнього музею в Лондоні, Музею візантійського та християнського мистецтва в Афінах (Шаронова, Анушевская). Такі срібні вироби, виконані із застосуванням техніки зерні, за матеріалами Музею історичних коштовностей України атрибутовані як київські, датовані XI - початком XIII ст. Однак у цьому випадку термін «візантійський» характеризує тип та рівень мистецтва, але не його походження чи місце виготовлення. Розвиваючи самобутнє образотворче мистецтво та вдосконалюючи значні технічні навички, середньовічний Київ започаткував власні багаті традиції у виробництві емалі, скані, черні й зерні, які сьогодні ототожнюються з києворуською добою (Рис. 3).

Однак їхні модифікації 3 напаяними назовні 5-6 променів пірамідальними кульками відомі за скарбами Старої Рязані, Тули (Рис. 2), Старого Осколу, Твері, Гродно (Оружейная палата, 2018: 21-22) тощо. 3 часом замість срібла для їхніх дешевших аналогів застосовували олов'яносвинцеві сплави. Інколи їх включали в парадний ансамбль прикрас знатної містянки разом із бармами - нашийно-нагрудною низзю медальйонів 3 емалевими зображеннями клейм із житія святих у стилі візантійських.

Висновки. Отже, виготовлення києворуських колтів 3 черню було поширено в княжих майстернях Києва та Чернігова, а надалі такі вироби знаходили у скарбах Старої Рязані, Новгорода тощо. Їхніми основними мотивами оздоблення були парні або одинарні зображення Песо-птахів і птахів, часто подібних до грифонів, або таких, що нагадували голубів (тема круговороту різних стихій і кохання-запліднення). Відчутними джерелами інспірацій тут були сиро-персько-тюрсько-візантійські прообрази. Подеколи техніку черні в таких творах замінювала чорна емаль, що свідчить про фактично один час виконання 3 емалевими колтами, який датується кінцем XI - початком XIII ст. Натомість зірчасті колти на 5-6 променів, запозичені з кримських прообразів візантійського часу (IX століття), інколи iз застосуванням техніки скані, були поширені, окрім києворуських міст, і на теренах етнічної Росії, де, ймовірно, і виготовлялися в місцевих майстернях ювелірів.

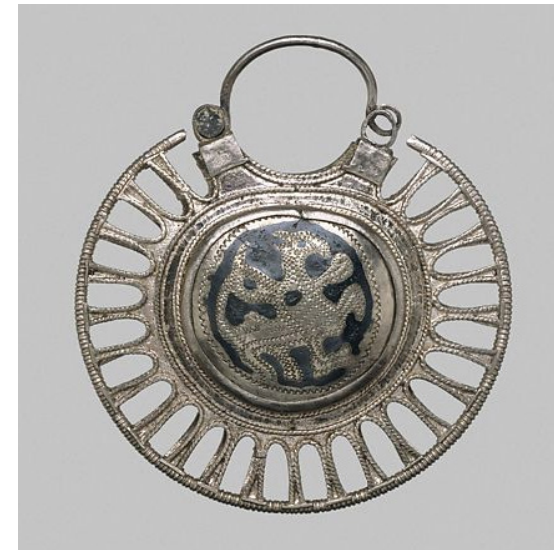

Рис. 1. Дископодібний срібний колт із чорнінням XI-XII ст. Київська Русь. Зберігасться у Metropolitan Museum of Art

Pl. 1. Disc-shaped silver kolt with nigellus technique XIXII centuries. Kievan Rus. Metropolitan Museum of Art
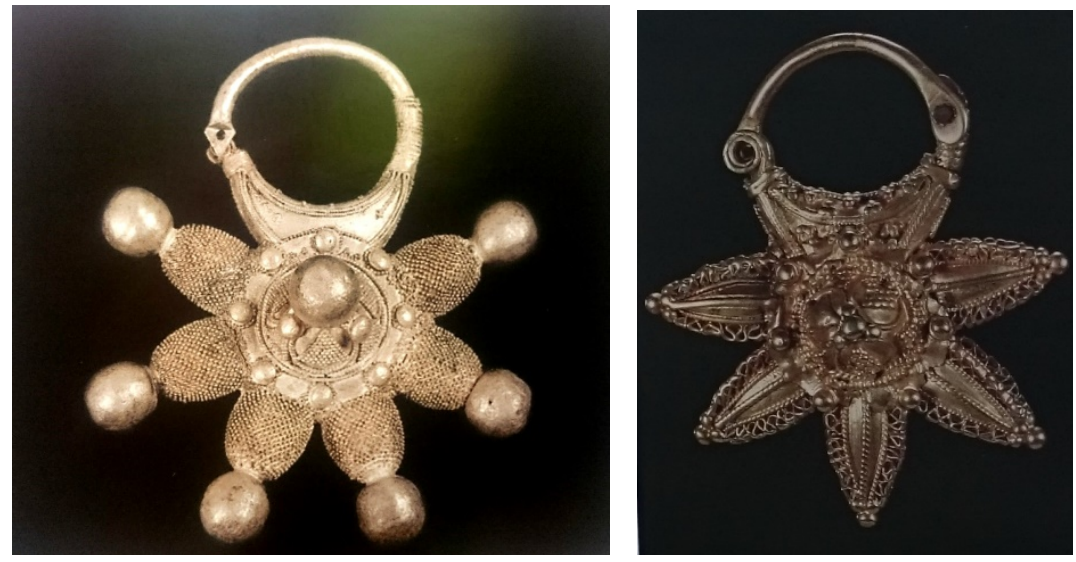

Рис. 2. Зірчастий срібний колт з Тульського кладу. XII ст.

Київська Русь. Зберігається в Оружейній палаті Московського Кремля

Pl. 2. Star-shaped silver kolt from Tula treasure. XII century. Kievan

Rus. Armory Chamber. Moscow Kremlin Museum
Рис. 3. Зірчастий золотий колт. XII - перша половина XIII ст. Київська Русь. Зберігається в Музеї історичних коштовностей України (філії НМІУ)

Pl. 3. Star-shaped golden kolt XII the first half of the XIII centuries. Kievan Rus. Museum of Historical Treasures of Ukraine 


\section{СПИСОК ВИКОРИСТАНИХ ДЖЕРЕЛ}

1. Айбабин А. И Археологическое наследие хазар времени создания каганата. МАИЭТ. 2013. Вып. XVIII. C. $277-315$.

2. Ароматические колты. 24 июля 2018 г. URL: https://was.media/2018-07-24-drevneruskie-ukrashenia/ (дата звернення: 07.04.2020).

3. Брайчевська О. А. Вироби дрібної пластики, монети і актові печатки як джерело для вивчення чоловічих головних уборів давньоруського часу. Старожитності Південної Русі : Мат-ли історико-археологічного семінару «Чернігів і його округа в IX-XIII ст.» (Чернігів, 15 травня 1990 р.). Чернігів, 1993. С. 112-117.

4. Васильев М. А. Древнерусский теоним Семаргль: историко-лингвистические этюды, I-II. Славянский альманах: Институт славяноведения РАН / отв. ред. К. В. Никифоров. Москва : Индрик, 2017. №1-2. С. 187-206.

5. Васильев М. А. Язычество восточных славян накануне крещения Руси. Религиозно-мифологическое взаимодействие с иранским миром / отв. ред. А. А. Турилов. Москва : Индрик, 1999. С. 328.

6. Даркевич В. П. Светское искусство Византии. Произведения византийского художественного ремесла в Восточной Европе X-XIII века. Москва : Искусство, 1975. С. 350.

7. Жилина Н. В. Древнерусские звездчатые колты (схема развития). Научные чтения памяти В. М. Василенко. Москва, 1997. № 1. С. 140-150.

8. Жилина Н. В. Лунничные серьги и колты средневекового Крыма (матрица из фондов ГАИМЗ «Херсонес Тавический»). Материаль по археологии, истории и этнографии Таврии. Симферополь, 2018. Вып. XXIII. C. 269-275.

9. Історія українського мистецтва : У 5 т. / НАН України, ІМФЕ ім. М. Т. Рильського ; голов. ред. Г. Скрипник ; ред. тому Р. Михайлова, Р. Забашта. Київ, 2008. Т. 1 : Мистецтво первісної доби та стародавнього світу. С. 710.

10. Ковтки. Словник украӥнської мови : в 4-х т. / автор-упор. Б. Грінченко. Київ : Наукова думка, 1996. Т. 2 : 3-H. С. 262.

11. Кондаков Н. Русские клады. Исследование древностей великокняжеского периода. Санкт-Петербург, 1896. T. 1. C. 183 .

12. Коруны, усерязи, колты. URL: https://was.media/2018-07-24-drevneruskie-ukrashenia/ (дата звернення: 7.04.2020).

13. Лунничные серьги и колты. URL: http://xn--80aajhqhktebqcvc2c9e6cj.xn--p1ai/finds/\%D0\%BB\%D1\%83\%D0 \%BD $\%$ D0\%BD $\%$ D0\%B8\%D1\%87\%D0\%BD\%D1\%8B\%D0\%B5-\%D1\%81\%D0\%B5\%D1\%80\%D1\%8C \%D0\%B3\%D 0\%B8-\%D0\%B8-\%D0\%BA\%D0\%BE\%D0\%BB\%D1\%82\%D1\%8B (дата звернення: 7.04.2020).

14. Макарова Т. Перегородчатые эмали Древней Руси. Москва : Наука, 1975. С. 127.

15. Макарова Т. Черневое дело Древней Руси. Москва : Наука, 1986. С. 156.

16. Оружейная палата. Путеводитель. Москва : Красная площадь, 2018. С. 288.

17. Рыбаков Б. А. Декоративно-прикладное искусство Руси X-XIII веков. Ленинград : Аврора, 1971 ; Оцифрування: Львів: Срібний Вовк, 2005. URL: http://www.rodnovery.ru/attachments/article/388/Dekorativnoprikladnoe_ iskusstvo_Rusi_X-XIII.pdf (дата звернення: 17.02.2020).

18. Рыбаков Б. А. Русалии и бог Симаргл-Переплут. Советская археология. 1967. № 2. С. 91-116.

19. Рябцева С. С. Древнерусские женские головные уборы с рясами и колтами. В камне и бронзе: сб. ст. в честь Анны Анисимовны Песковой. Санкт-Петербург, 2017. С. 499-510.

20. Рябцева С. Древнерусский ювелирный убор. Санкт-Петербург : Нестор-История, 2005. С. 384.

21. Хайрединова Э. Х. Византийские кресты с инкрустацией из Юго-Западного Крыма. Вестник ВолГУ. Серия 4, История. Регионоведение. Международные отношения. 2017. Т. 22. № 5. С. 86-99.

22. Шаронова Е., Анушевская А. Серьги Византии (Средний период, 9-12 вв.). URL: http://south-rus.org/ articles/?ELEMENT_ID=8921 (дата звернення: 08.04.2020).

\section{REFERENCES}

1. Aybabin A.I Arkheologicheskoye naslediye khazar vremeni sozdaniya kaganata. [Archeological heritage of the Khazars of the time of the creation of the Kaganate]. // MAEET. 2013, Issue. XVIII. pp. 277-315 [in Russian].

2. Aromaticheskiye kolty. (24 iyulya 2018 h.) [Aromatic kolts. (July 24, 2018)]. URL: https://was.media/2018-07-24drevneruskie-ukrashenia/ (date of the application: January 13, 2020) [in Russian].

3. Braychevs'ka O. A. Vyroby dribnoyi plastyky, monety i aktovi pechatky yak dzherelo dlya vyvchennya cholovichykh holovnykh uboriv davn'orus'koho chasu [Products of small plastic, coins and nudity seals as a source for the study of men's hats of ancient times]. // Antiquity of southern Russia. Mat-li of the historical-archeological seminar «Chernihiv and its district in IX-XIII centuries» (Chernihiv, May 15, 1990). Chernihiv, 1993, pp, 112-117 [in Russian].

4. Vasil'yev M. A. Drevnerusskiy teonim Semargl: istoriko-lingvisticheskiye etyudy I-II. [The Old Russian Theonym Semargl: Historical and Linguistic Studies I-II]. // Slavic almanac: Institute of Slavic Studies, RAS / ed. K. V. Nikiforov. Moscow: Indrik, 2017, Nr. 1-2, pp. 187-206 [in Russian].

5. Vasil'yev M. A. YAzychestvo vostochnykh slavyan nakanune kreshcheniya Rusi. Religiozno-mifologicheskoye vzaimodeystviye s iranskim mirom. [Paganism of the Eastern Slavs on the eve of the baptism of Russia. Religious and mythological interaction with the Iranian world]. Holes ed. A. A. Turilov. Moscow: Indrik, 1999, p. 328 [in Russian].

6. Darkevich V. P. Svetskoye iskusstvo Vizantii. Proizvedeniya vizantiyskogo khudozhestvennogo remesla v Vostochnoy Yevrope X-XIII veka. [Secular art of Byzantium. Works of Byzantine art craft in Eastern Europe X-XIII century]. Moscow: Art, 1975, p. 350 [in Russian]. 
7. Zhilina N. V. Drevnerusskiye zvezdchatyye kolty (skhema razvitiya). [Old Russian star-shaped kolts (development chart)] // Scientific readings in memory of V. M. Vasilenko. Moscow, 1997, Nr. 1, pp. 140-150 [in Russian].

8. Zhilina N. V. Lunnichnyye ser'gi i kolty srednevekovogo Kryma [Lunar earrings and kolts of medieval Crimea]. (matrix from the GAIMZ «Tavic Khersones» funds) // Materials on archeology, history and ethnography of Tavria. Vol. XXIII. Simferopol, 2018, pp. 269-275 [in Russian].

9. Istoriya ukrayins'koho mystetstva [History of Ukrainian Art]. In 5 volumes / NAS of Ukraine, IMF them. MT Rylsky; heads. ed. D. Skripnik; ed. so R. Mikhailova, R. Toast. Kyiv, 2008, Vol. 1: The Art of the Ancient Age and the Ancient World, pp, 710 [in Ukrainian].

10. Kovtky // Slovnyk ukrayins'koyi movy. [Kovtky // Dictionary of the Ukrainian language] in 4 volumes / authoremphasis. B. Grinchenko. T. 2. Z - N. Kyiv: Scientific Thought, 1996, p. 262 [in Ukrainian].

11. Kondakov N. Russkiye klady. Issledovaniye drevnostey velikoknyazheskogo perioda. [Russian treasures. Ancient Studies of the Grand Ducal Period]. T. 1. St. Petersburg, 1896, p. 183 [in Russian].

12. Koruny, useryazy, kolty. [Crowns, mules, kolts. ]. URL: https://was.media/2018-07-24-drevneruskie-ukrashenia/ (date of the application: April 07, 2020) [in Russian].

13. Lunnichnyye ser'gi i kolty. [Lunar earrings and kolts.]. URL: http: //xn--80aajhqhktebqcvc2c9e6cj.xn--p1ai/finds/\% D0\%BB\%D1\%83\%D0\%BD\%D0\%BD\%D0\%B8\%D1\%87\%D0\%BD\%D1\%8B \% D0\% B5-\% D1\% 81\% D0\% B5\% D1\% $80 \%$ D1\% 8C\% D0\% B3\% D0\% B8-\% D0\% B8-\% D0\% BA\% D0\% BE\% D0\% BB\% D1\% 82\% D1\% 8B (date of the application: April 07, 2020) [in Russian].

14. Makarova T. Peregorodchatyye emali Drevney Rusi. [Cloisonne of Ancient Rus]. Moscow: Nauka, 1975, p. 127 [in Russian].

15. Makarova T. Chernevoye delo Drevney Rusi. [The nigellus technology of Ancient Rus]. Moscow: Nauka, 1986. p. 156 [in Russian].

16. Oruzheynaya palata. Putevoditel' [Armory Chamber. Guide]. Moscow: Red Square, 2018, p. 288 [in Russian].

17. Rybakov B. A. Dekorativno-prikladnoye iskusstvo Rusi X-XIII vekov. [Decorative and applied art of Russia of the X-XIII centuries]. Leningrad: Aurora, 1971. (Digitized: Lviv: Sribny Vovk, 2005). URL: http://www.rodnovery.ru/ attachments/article/388/Dekorativnoprikladnoe_iskusstvo_Rusi_X-XIII. (date of the application: February 17, 2020) [in Russian].

18. Rybakov B. A. Rusalii i bog Simargl-Pereplut. [Rusalii and the God Simargl-Pereplut]. // Soviet archeology. 1967, Nr. 2, pp. 91-116 [in Russian].

19. Ryabtseva S. S. Drevnerusskiye zhenskiye golovnyye ubory s ryasami i koltami. [Old Russian women's hats with robes and kolts]. // In stone and bronze: collection. Art. in honor of Anna Anisimovna Peskova. St. Petersburg, 2017, pp. 499-510 [in Russian].

20. Ryabtseva S. Drevnerusskiy yuvelirnyy ubor. [Old Russian jewelry]. St. Petersburg: Nestor-Istoriya, 2005, p. 384 [in Russian].

21. Khayredinova E. Kh. Vizantiyskiye kresty s inkrustatsiyey iz Yugo-Zapadnogo Kryma. [Byzantine crosses with inlay from the South-Western Crimea]. Bulletin of VolSU. Series 4, History. Regional studies. International relationships. 2017, T. 22. Nr. 5, pp. $86-99$ [in Russian].

22. Sharonova Ye., Anushevskaya A. Ser'gi Vizantii.(Sredniy period, 9-12 vv.). [Earrings of Byzantium (Middle period, 9-12 centuries)]. URL: http://south-rus.org/articles/?ELEMENT_ID=8921 (date of the application: April 07, 2020) [in Russian]. 